\title{
Audit on the Application of Surfactant in Premature Babies in Assiut University Children Hospital
}

\author{
RAFIK M.B. HANNA, M.Sc.; GIHAN M. KAMAL EL-DEIN, M.D. and ZEINAB M.M. EL-KADY, M.D. \\ The Department Pediatrics, Faculty of Medicine, Assiut University, Assiut, Egypt
}

\begin{abstract}
Background: To evaluate the use of exogenous natural surfactant for Respiratory Distress Syndrome (RDS) in premature babies, identify areas where European Consensus Guidelines on the Management 2013 Update, modified by The Egyptian Consensus on the Management of Neonatal Respiratory Distress Syndrome in Preterm Infants 2014 are applied to as a reference standard in Assiut University Children Hospital and identify those points to be targeted for improvement.
\end{abstract}

Patients and Methods: A retrospective audit was undertaken over a 12-month period between 1 st of January, 2016 to the 31 st of December 2016. It included all babies less than 37 weeks gestation with respiratory distress syndrome who received surfactant as a rescue treatment, guided by European Consensus Guidelines on the Management 2013 Update, modified by The Egyptian Consensus on the Management of Neonatal Respiratory Distress Syndrome in Preterm Infants 2014 and admitted to Neonatal Intensive Care Unit of Assiut University Children Hospital during this period.

Results: All cases with severe respiratory distress that needed surfactant injection and admitted in Assiut university children hospital from 1 st of January to $31^{\text {th }}$ of December 2016 were included in the study. The study included 50 patients with severe respiratory distress syndrome.

Conclusion: Surfactant replacement therapy has been available for about 37 years, revolutionizing neonatal respiratory care after its introduction in the 1980s. Along with antenatal steroids, surfactants improve survival for preterm babies and they are now recommended routinely as early in the course of Respiratory Distress Syndrome (RDS) as possible. The present study aimed to evaluate the use of surfactant for Respiratory Distress Syndrome (RDS) in premature babies admitted at NICU of Assiut university children hospital during the period from 1 st of January to 31 st of December 2016 using European Consensus Guidelines on the Management 2013 Update, modified by The Egyptian Consensus on the Management of Neonatal Respiratory Distress Syndrome in Preterm Infants 2014.

The study included 50 cases with respiratory distress syndrome who received surfactant therapy.

Correspondence to: Rafik M.B. Hanna,

E-mail: rafikhanna30@gmail.com
- Data of the study showed that treatment regimens for cases of RDS in Assiut University Children Hospital partially followed the reference standard of the study concerning application of surfactant in premature babies.

- Data of the gestational age and weight and sex were recorded in $100 \%$ of cases.

- Data concerning clinical evaluation of the studied group were recorded in $100 \%$ cases.

- Data concerning obstetric history and prenatal care were fulfilled well but there were no records concerning receiving a course of antibiotics if there is preterm, pre-labor rupture of membranes nor short term tocolytic drugs. Also, the data showed that only $28 \%$ of mothers received a course of prenatal steroids if preterm labor was expected.

- Data concerning delivery room stabilization were fulfilled well but there were no records concerning delayed cord clamping and there was no available CPAP at the delivery room nor plastic bag for stabilization of preterm baby with respiratory distress syndrome.

- Data concerning surfactant therapy were fulfilled well but there was no data that any case received prophylactic surfactant therapy neither with nor without INSURE technique.

- Data concerning respiratory support were fulfilled well but no cases received CPAP as a 1 st line respiratory support for any spontaneously breathing preterm with RDS at delivery room and no cases received CPAP with early rescue surfactant which is now considered the optimal management for babies with RDS.

- Data concerning supportive care were fulfilled in $100 \%$ of cases but no cases received enteral feeding from the 1 st day which is strongly recommended with careful fluid balance for early aggressive nutritional support.

- Data concerning prognosis showed that the vast majority of dead cases were below 32 weeks and below $1 \mathrm{KG}$.

Key Words: Antenatal corticosteroids - Continuous positive airway pressure-Meconium aspiration syndrome - Nasal intermittent positive pressure ventilation - Necrotizing enterocolitis - Patent ductus arteriosus - Respiratory distress syndrome.

\footnotetext{
Abbreviations:

ACS : Antenatal Corticosteroid.

HMD: Hyaline Membrane Disease.
} 


\section{Introduction}

IN 1959, Avery and Mead reported on the deficiency of surface-active material in the lungs of preterm babies with respiratory distress syndrome (RDS). This led to clinical trials of artificial surface-active materials in babies with RDS.

The term "hyaline membrane disease" refers to the histological aspect of the most frequent pulmonary pathology in preterm newborn patients [7].

Surfactant deficiency in the immature lungs causes alveolar instability and collapse, capillary edema and the formation of hyaline membrane. Thus, the hyaline membranes are epiphenomena and are not the cause of respiratory failure in infants with immature lungs. This definition is presently used to indicate surfactant deficit alone and should not be used for other causes of respiratory distress, Clinicians prefer to talk of "respiratory distress syndrome" (RDS) [1].

Improvement in neonatal treatment has changed the natural course of the illness, its clinical and radiological features and has enabled extremely low birth weight newborns (ELBW) to survive, Alveoli paucity and pulmonary interstitial thickness in ELBW impair gas exchange and may necessitate prolonged ventilation treatment, increasing the risk of ventilator-induced lung injury (VILI) and bronchopulmonary dysplasia [13].

RDS, therefore, is a complex illness where pulmonary immaturity and surfactant deficit play a role together with other pathological conditions that determine the course of the illness and both short and long-term results.

RDS is usually defined by the presence of acute respiratory distress with disturbed gas exchange in a preterm infant with a typical clinical course or X-ray (ground glass appearance, air bronchograms and reduced lung volume [12]

The lungs of preterm babies with RDS are both anatomically and biochemically immature; they neither synthesize nor secrete surfactant well.

Surfactant normally lines the alveolar surfaces in the lung, thereby reducing surface tension and preventing atelectasis [8].

Surfactant replacement therapy, either as a rescue treatment or a prophylactic natural surfactant therapy, reduces mortality and several aspects of morbidity in babies with RDS. These morbidities include deficits in oxygenation, the incidence of pulmonary air leaks (pneumothorax and pulmonary interstitial emphysema) and the duration of ventilatory support.

Surfactant replacement increases the likelihood of surviving without bronchopulmonary dysplasia (BPD, also known as chronic lung disease of the preterm) [2]

Babies treated with surfactants have shorter hospital stays and lower costs of intensive car treatment compared with randomized control infants receiving no surfactants.

Surfactant replacement therapy has been available for about 25 years, revolutionizing neonatal respiratory care after its introduction in the 1980s. Along with antenatal steroids, surfactants improve survival for preterm babies and they are now recommended routinely as early in the course of Respiratory Distress Syndrome (RDS) as possible [1] . Prophylactic treatment, although appearing ideal, exposes some babies who might manage perfectly well on Continuous Positive Airway Pressure (CPAP) to intubation and ventilation, which may increase the risk of bronchopulmonary dysplasia. Recent studies attempt to determine the optimal balance between avoiding ventilation by using CPAP and giving surfactant in a timely fashion to babies with RDS. The key feature of Respiratory Distress Syndrome (RDS) is the insufficient production of surfactant in the lungs of preterm infants [11]. As a result, researchers have looked into the possibility of surfactant replacement therapy as a means of preventing and treating RDS. We sought to identify the role of surfactant in the prevention and management of RDS, comparing the various types, doses, and modes of administration, and the recent development [9].

Natural, or animal-derived, surfactant is currently the surfactant of choice in comparison to protein-free synthetic surfactant. However, it is hoped that the development of protein-containing synthetic surfactant, such as lucinactant, will rival the efficacy of natural surfactants, but without the risks of their possible side effects. Administration techniques have also been developed with nasal Continuous Positive Airway Pressure (nCPAP) and selective surfactant administration being now recommended, multiple surfactant doses have also reported better outcomes [10]. An aerosolized form of surfactant is being trialed in the hope that surfactant can be administered in a non-invasive way [3]. Overall, the advancement, concerning the structure of surfactant and its mode of administration, 
offers an encouraging future in the management of RD.

\section{Patients and Methods}

All cases with severe respiratory distress that needed surfactant injection and admitted in Assiut university children hospital from 1 st of January to $31^{\text {th }}$ of December 2016 were included in the study. The study included 50 patients with severe respiratory distress syndrome.

Inclusion criteria: All the recorded premature cases with Respiratory Distress Syndrome (RDS) admitted to neonatal intensive care unit during aforementioned period that received surfactant therapy and referred from Hospital of Women's Health in Assiut were included.

Exclusion criteria: All the recorded cases during aforementioned period who were admitted to neonatal unit with any other type of respiratory distress rather than respiratory distress syndrome were excluded.

Tools of study: Reviewing sheets of patient with severe respiratory distress admitted to Assiut University Children Hospital during the study duration.

The following data were collected and recorded for each patient in a master sheet for management of RDS by Surfactant:

- Socio-demographic characteristics such as name, gestational age and sex.

- Data about clinical evaluation of a neonate with respiratory distress using Downes' score as air entry, retractions, grunting and cyanosis.

- Data about former, present obstetric history (maternal age, fetal distress and perinatal asphyxia multiple gestation, prior preterm delivery, maternal diabetes and mode of delivery and prenatal care received by women at high risk of preterm birth as being transferred out to perinatal centers with experience in management of RDS and receiving antenatal steroids or tocolytics and antibiotics if there is history of PROM or not.

- Data about delivery room stabilization as cord clamping, stabilization by $21 \%-30 \%$ oxygen, using CPAP, and stabilization under radiant warmer.

- Data about Surfactant therapy as it's nature either natural or synthesized, if we use prophylactic surfactant therapy, type of surfactant used, if we use INSURE technique and if repeated doses of surfactant needed.
- Data about further respiratory support as use of oxygen, CPAP, MV and caffeine.

- Data about prognosis:To identify areas where European Consensus Guidelines on the Management 2013 Update, modified by The Egyptian Consensus on the Management of Neonatal Respiratory Distress Syndrome in Preterm Infants 2014 are applied to as a reference standard in Assiut University Children Hospital and identify those points to be targeted for improvement.

\section{Results}

Table (1) showed that the majority of cases that needed surfactant injection were males $(72 \%)$, very preterm babies ( 28 to $<32$ weeks gestational age) (72\%) and VLBW <1.5 KG (48\%).

Table (2) showed evaluation of respiratory distress using downes' score, it showed that the majority of cases that needed surfactant injection were distressed with Downe score 4-7 (80\%).

Table (3) showed that the majority of cases that needed surfactant injection had a previous history of prior preterm delivery (44\%) and most of them delivered by elective CS (76\%).

The table also showed that only $28 \%$ of the mothers of theses neonates received a prophylactic course of steroids prior to delivery.

Despite the importance of prenatal care as a cornerstone of a healthy pregnancy, labor, and baby, no sufficient information could be received especially about administration of antenatal corticosteroids.

Being with or without tocolytics and antibiotics that will affect the decision making for use of surfactant in premature babies $<30$ wks. Accurate and complete documentation in the medical record is lacking. Most of information was inaccurate, insufficient and derived from the parents.

Table (4) showed that there was lack of facilities at the delivery room as there was no available CPAP nor surfactant that could be used which delayed the management of cases of RDS which worsened the prognosis.

Table (5) showed that no cases received prophylactic surfactant therapy which is of great benefit to extremely preterm infants in whom the mother has not had antenatal steroids or those who require intubation for stabilization.

The table also showed that only $4 \%$ of cases received repeated doses of surfactant inspite of 
presence of signs of respiratory distress even after injection in some cases.

INSURE technique was not used for rescue surfactant administration.

Table (6) showed that only $16 \%$ of cases that needed surfactant injection were connected to CPAP which should be started from birth in all babies at risk of RDS, such as those $<30$ weeks' gestation who do not need MV, until their clinical status can be assessed.
The table also showed that there were no cases received CPAP with early rescue surfactant which considered the optimal management for babies with RDS.

Table (7) showed that no cases received enteral feeding on day 1 of life but Careful fluid balance was required with early aggressive nutritional support using parenteral nutrition whilst enteral feeding was being established.

Table (8) Showed that the vast majority of dead cases were below 32 weeks and below $1 \mathrm{KG}$.

Table (1): Demographic data of the studied group.

\begin{tabular}{|c|c|c|c|}
\hline Item & $\mathrm{N}$ & $\%$ & $p$-value \\
\hline \multicolumn{4}{|l|}{ Gestation at Birth: } \\
\hline 28 to $<32$ weeks & 36 & 72 & - \\
\hline 32 to $<34$ weeks & 6 & 12 & - \\
\hline 34 to $<37$ weeks & 8 & 16 & - \\
\hline \multicolumn{4}{|l|}{ Birth Weight (kilograms): } \\
\hline$<1.0 \mathrm{~kg}$ & 14 & 28 & - \\
\hline$<1.5 \mathrm{~kg}$ & 24 & 48 & - \\
\hline $1.5: 2.499 \mathrm{~kg}$ & 12 & 24 & - \\
\hline \multicolumn{4}{|l|}{ Sex: } \\
\hline Male & 36 & 72 & $<0.001 * *$ \\
\hline Female & 14 & 28 & $<0.001^{*}$ \\
\hline \multicolumn{4}{|c|}{$\begin{array}{l}\text { *: Statistically significant difference }(p<0.05) \text {. } \\
\text { **: Statistically significant difference }(p<0.01)\end{array}$} \\
\hline \multicolumn{4}{|c|}{ Table (2): Evaluation of respiratory distress using downes' score. } \\
\hline Item & $\mathrm{N}$ & $\%$ & $p$-value \\
\hline \multicolumn{4}{|l|}{ Air entry: } \\
\hline Good bilateral & 12 & 24 & $<0.001 * *$ \\
\hline Mild Decrease in Air entry & 8 & 16 & $<0.001 * *$ \\
\hline No Air Entry & 30 & 60 & $0.046^{*}$ \\
\hline \multicolumn{4}{|l|}{ Respiratory rate: } \\
\hline$<60$ & 0 & - & - \\
\hline $60-80$ & 12 & 24 & $<0.001 * *$ \\
\hline$>80$ & 38 & 76 & $<0.001 * *$ \\
\hline \multicolumn{4}{|l|}{ Retractions: } \\
\hline No Retractions & 44 & 88 & $<0.001 * *$ \\
\hline Mild Retractions & 2 & 4 & $<0.001 * *$ \\
\hline Severe Retractions & 4 & 8 & $<0.001 * *$ \\
\hline \multicolumn{4}{|l|}{ Grunting: } \\
\hline No Grunting & 10 & 20 & $<0.001 * *$ \\
\hline Audible by stethoscope & 7 & 14 & $<0.001 * *$ \\
\hline Audible with ear & 33 & 66 & $0.002 * *$ \\
\hline \multicolumn{4}{|l|}{ Cyanosis: } \\
\hline No Cyanosis & 42 & 84 & $<0.001 * *$ \\
\hline Cyanosis relieved by $\mathrm{O}_{2}$ & 0 & - & - \\
\hline Cyanosis on $\mathrm{O}_{2}$ & 8 & 16 & $<0.001 * *$ \\
\hline \multicolumn{4}{|l|}{ Downe' score: } \\
\hline $4-7$ & 40 & 80 & $<0.001 * *$ \\
\hline$>7$ & 10 & 20 & $<0.001 * *$ \\
\hline$<4$ & 0 & - & - \\
\hline
\end{tabular}


Table (3): Former, present obstetric history and prenatal care received by women at high risk of preterm birth in our study.

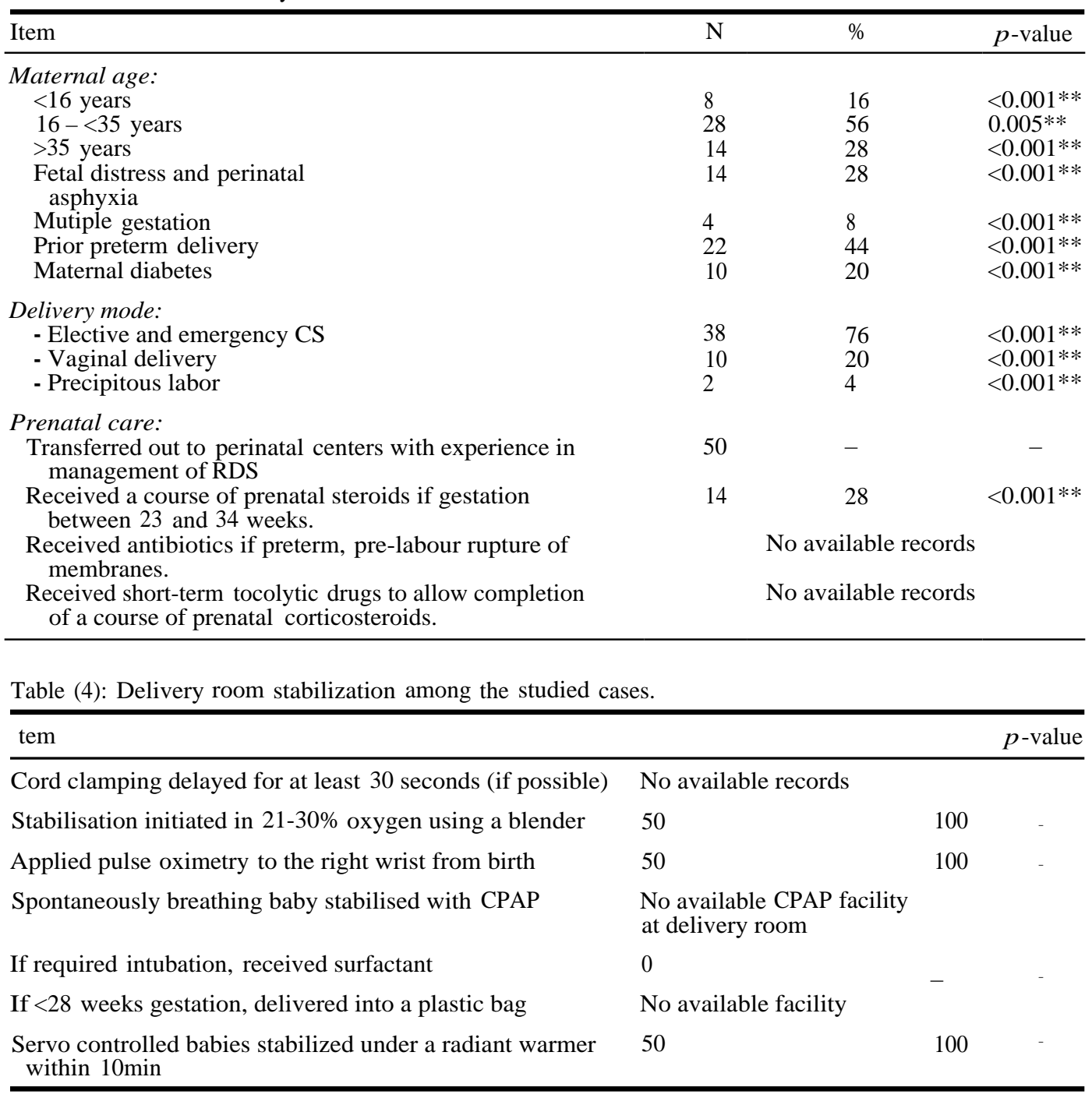

Table (5): Surfactant Therapy among the studied cases.

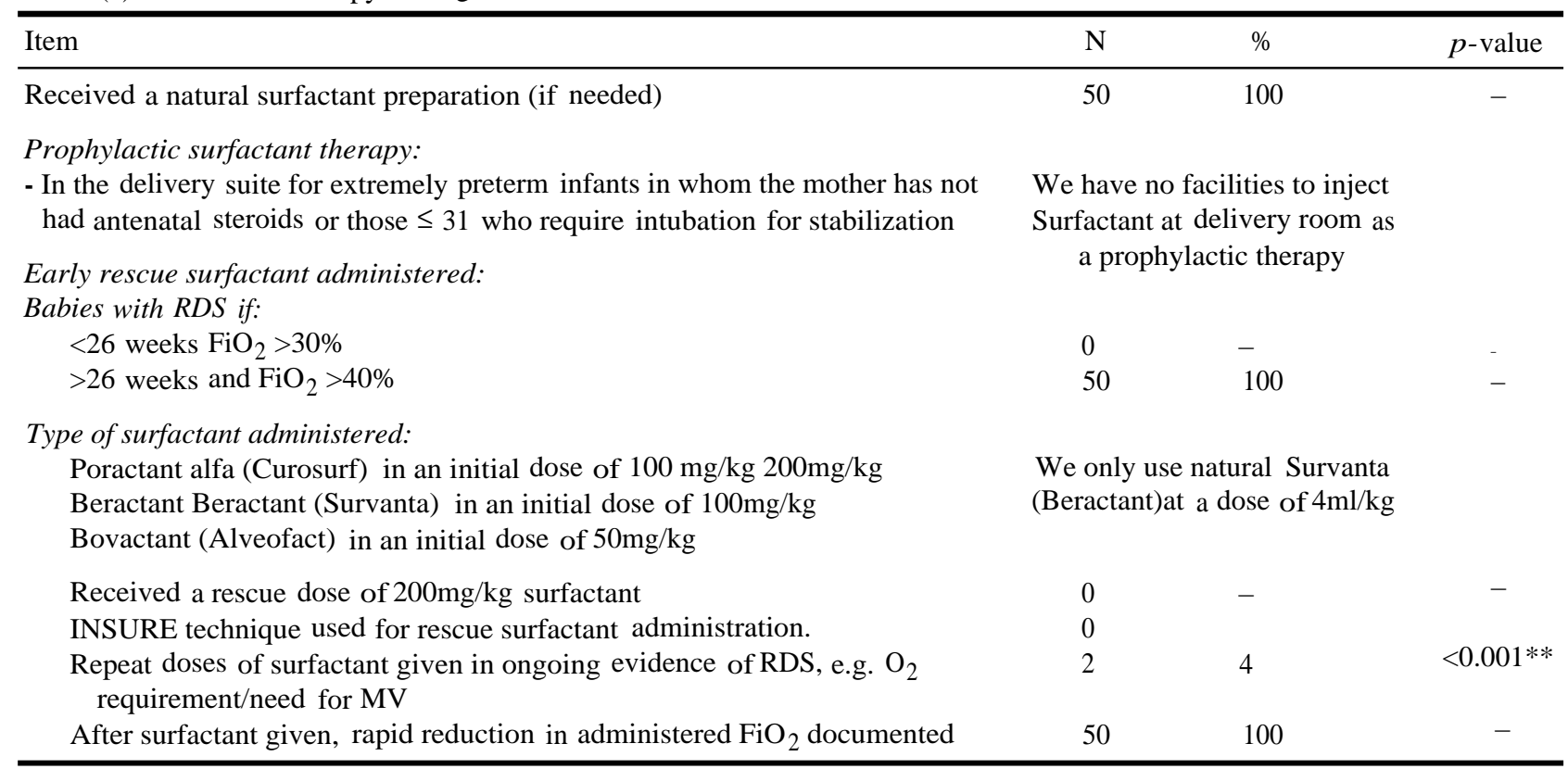


Table (6): Further Respiratory Support among the studied cases.

\begin{tabular}{|c|c|c|c|}
\hline Item & $\mathrm{N}$ & $\%$ & $p$-value \\
\hline \multicolumn{4}{|l|}{ Oxygen Indications: } \\
\hline Severe respiratory distress & 40 & 80 & $<0.001 * *$ \\
\hline Low $\mathrm{O} 2$ saturation in air & 50 & 100 & _ \\
\hline Target saturations $\left[\mathrm{SaO}_{2}\right]$ 90-95\% in preterm infants & 50 & 100 & \\
\hline \multicolumn{4}{|l|}{ Non-Invasive Respiratory Support: } \\
\hline $\begin{array}{l}\text { CPAP first-line respiratory support used for RDS, if not } \\
\text { intubated }\end{array}$ & \multicolumn{2}{|c|}{$\begin{array}{l}\text { No available early CPAP facility } \\
\text { at delivery room }\end{array}$} & \\
\hline CPAP delivered through mask or bi-nasal prongs & 8 & 16 & $<0.001 * *$ \\
\hline $\mathrm{CPAP}$ pressure of at least $6 \mathrm{~cm}$ of water applied & 8 & 16 & $<0.001 * *$ \\
\hline CPAP with early rescue surfactant & 0 & - & - \\
\hline \multicolumn{4}{|l|}{ Mechanical Ventilation Strategies: } \\
\hline $\begin{array}{l}\text { Targeted tidal volume ventilation If not used, what is } \\
\text { documented reason why? (E.g. high leak,used. another } \\
\text { lung pathology etc.) }\end{array}$ & \multicolumn{2}{|c|}{$\begin{array}{l}\text { Our machines deliver only Pressure } \\
\text { controlled ventilation }\end{array}$} & \\
\hline $\begin{array}{l}\text { Caffeine used in baby if; apnoea, or, facilitate weaning } \\
\text { from MV }\end{array}$ & 50 & 100 & - \\
\hline $\begin{array}{l}\text { Tapering course of steroids (dexamethasone) used if } \\
\text { remains on MV after 1-2 weeks }\end{array}$ & 8 & 16 & $<0.001 * *$ \\
\hline
\end{tabular}

Table (7): Supportive care among the studied cases.

\begin{tabular}{|c|c|c|c|}
\hline Item & $\mathrm{N}$ & $\%$ & $p$-value \\
\hline Body temperature Maintained in the normal range & 50 & 100 & - \\
\hline $\begin{array}{l}\text { Antibiotics started until sepsis has been ruled out (unless the risk of infection is low, } \\
\text { for example after an elective caesarean section }\end{array}$ & 50 & 100 & - \\
\hline Parenteral nutrition started on day 1 of life & 50 & 100 & - \\
\hline Minimal enteral feeding/trophic feeds started on day 1 of life & 0 & - & - \\
\hline $\begin{array}{l}\text { Blood pressure monitored regularly, aiming to maintain normal tissue perfusion, if } \\
\text { necessary usinginotropes }\end{array}$ & 50 & 100 & - \\
\hline $\mathrm{Hb}$ conc. maintained within normal range & 50 & 100 & - \\
\hline PDA, if needing treatment, is medically managed (ibuprofen/indomethacin) & 13 & 100 & - \\
\hline
\end{tabular}

Table (8): Prognosis of the studied Group of RDS.

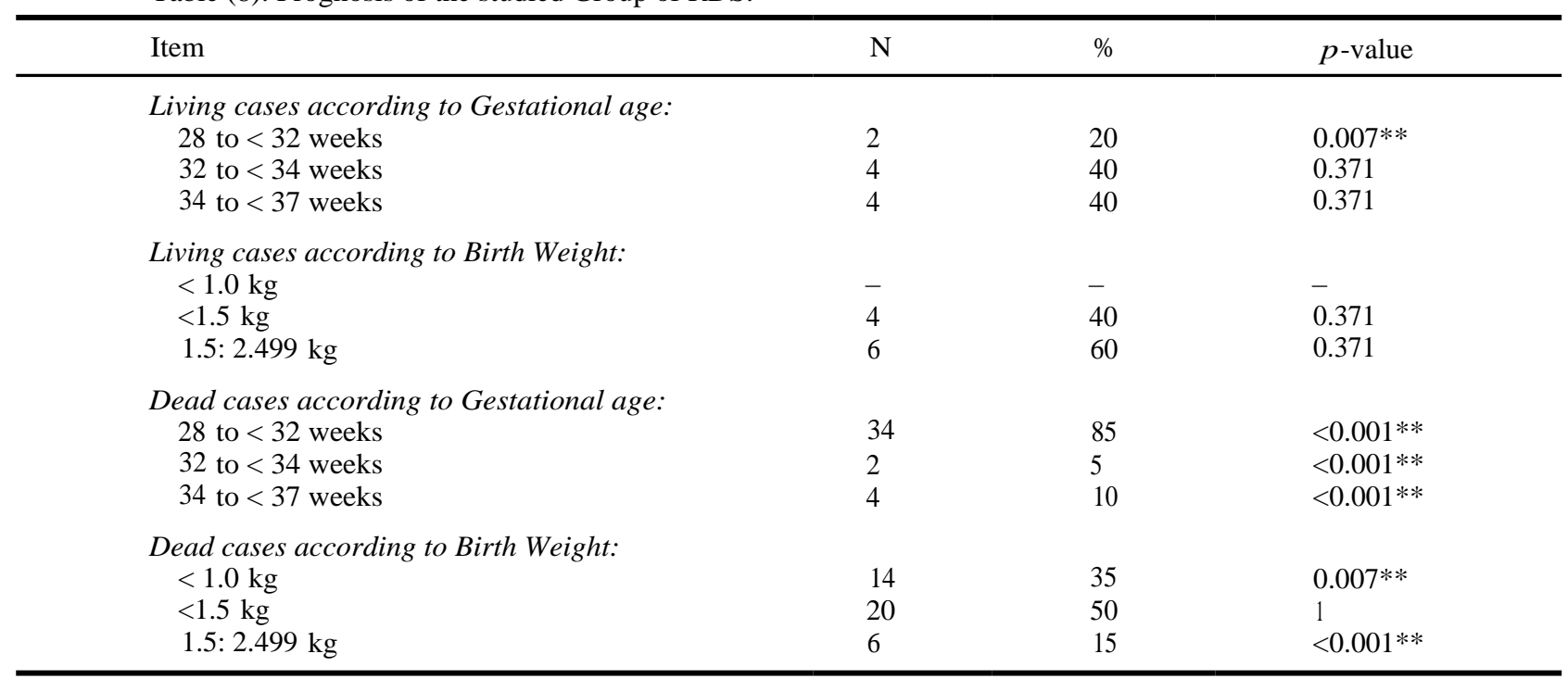




\section{Discussion}

Surfactant replacement therapy has been available for about 25 years, revolutionizing neonatal respiratory care after its introduction in the 1980s. Along with antenatal steroids, surfactants improve survival for preterm babies and they are now recommended routinely as early in the course of Respiratory Distress Syndrome (RDS) as possible. Prophylactic treatment, although appearing ideal, exposes some babies who might manage perfectly well on Continuous Positive Airway Pressure (CPAP) to intubation and ventilation, which may increase the risk of bronchopulmonary dysplasia. Recent studies attempt to determine the optimal balance between avoiding ventilation by using CPAP and giving surfactant in a timely fashion to babies with RDS. The key feature of Respiratory Distress Syndrome (RDS) is the insufficient production of surfactant in the lungs of preterm infants. As a result, researchers have looked into the possibility of surfactant replacement therapy as a means of preventing and treating RDS [4]

We sought to identify the role of surfactant in the prevention and management of RDS, comparing the various types, doses, and modes of administration, and the recent development.

Natural, or animal-derived, surfactant is currently the surfactant of choice in comparison to protein-free synthetic surfactant [5]. However, it is hoped that the development of protein-containing synthetic surfactant, such as lucinactant, will rival the efficacy of natural surfactants, but without the risks of their possible side effects. Administration techniques have also been developed with nasal Continuous Positive Airway Pressure (nCPAP) and selective surfactant administration now recommended, multiple surfactant doses have also reported better outcomes. An aerosolized form of surfactant is being trialed in the hope that surfactant can be administered in a non-invasive way. Overall, the advancement, concerning the structure of surfactant and its mode of administration, offers an encouraging future in the management of RD.

It is very important to receive proper prenatal care as prenatal care is a cornerstone of a healthy pregnancy, labor, and baby [6]

Interventions to prevent RDS should begin before birth and involve both pediatricians and obstetricians as part of the perinatal team. The care team must be well attuned as prevention is better than a cure [14].
Enhance communication among healthcare team members that influences the quality of working relationships, job satisfaction and has profound impacts on patient safety through accurate and complete documentation in the medical record especially the administration of antenatal corticosteroids (with or without tocolytics) that will affect the decision making for use of surfactant in premature babies <37 weeks [15].

Delivery room should be equipped with Facilities as Plastic bags to prevent hypothermia, CPAP machine or T-piece and Surfactant for use once indicated [16]

If possible, delay clamping of the umbilical cord for at least $30 \mathrm{~s}$ with the baby held below the mother to promote placento-fetal transfusion.

Try to initiate Early CPAP and selective surfactant administration to avoid intubation and reduce rates of death.

An experienced neonatal resuscitation/stabilization team is essential for surfactant administration [17].

Select the type of surfactant in terms of efficacy, safety, and total number of doses per patient and cost.

MV can be avoided by using the 'INSURE' (Intubate-SURfactant-Extubate to CPAP) technique

CPAP should be started from birth in all babies at risk of RDS, such as those $<30$ weeks' gestation who do not need MV, until their clinical status can be assessed [18]

CPAP with early rescue surfactant should be considered the optimal management for babies with RDS.

MV should be used to support babies when other methods of respiratory support have failed [19].

Minimal enteral feeding should also be started from the first day.

Careful fluid balance is required with early aggressive nutritional support using parenteral nutrition whilst enteral feeding is being established

Adherence to guidelines as a reference standard if possible to improve the prognosis [20]

Consideration should be given to pharmacological closure of the ductus arteriosus. 


\section{References}

1- ABDEL-LATIF M.E. and OSBORN D.A.: Laryngeal mask airway surfactant administration for prevention of morbidity and mortality in preterm infants with or at risk of respiratory distress syndrome. Cochrane Database Syst. Rev., 6: CD008309, 2011.

2- BANCALARI E. and CLAURE N.: The evidence for noninvasive ventilation. Arch Dis Child Fetal Neonatal Ed., 98: F98-F102, 2013.

3- FUCHS H., LINDNER W., LEIPRECHT A., MENDLER M.R. and HUMMLER H.D.: Predictors of early nasal CPAP failure and effects of various intubation criteria on the rate of mechanical ventilation in preterm infants of $<29$ weeks gestational age. Arch Dis Child Fetal Neonatal Ed., 96: F343-F347, 2011

4- OHLSSON A., WALIA R. and SHAH S.S.: Ibuprofen for the treatment of patent ductus arteriosus in preterm and/or low birth weight infants. Cochrane Database Syst. Rev., 30: CD003481, 2010.

5- GÖPEL W., KRIBS A., ZIEGLER A., LAUX R., HOEHN T., et al.: Avoidance of mechanical ventilation by surfactant treatment of spontaneously breathing preterm infants (AMV): An open-label, randomised, controlled trial. Lancet, 378: 1627-1634, 2011.

6- HANSEN A.K., WISBORG K., ULDBJERG N. and HENRIKSEN T.B.: Risk of respiratory morbidity in term infants delivered by elective caesarean section: Cohort study. BMJ, 336: 85-87, 2008.

7- O'DONNELL C.P. and SCHMOLZER G.M.: Resuscitation of preterm infants: Delivery room interventions and their effect on outcomes. Clin. Perinatol., 39: 857-869, 2010.

8- HENDERSON-SMART D.J. and DAVIS P.G.: Prophylactic methylxanthines for endotracheal extubation in preterm infants. Cochrane Database Syst. Rev., 8: CD000139, 2010.

9- HITZERT M.M., BENDERS M.J., ROESCHER A.M., VAN BEL F., de VRIES L.S., et al.: Hydrocortisone vs. dexamethasone treatment for bronchopulmonary dysplasia and their effects on general movements in preterm infants. Pediatr Res., 71: 100-106, 2012.

10- MORLEY C.J.: Volume-limited and volume targeted ventilation. Clin. Perinatol., 39: 513-523, 2012.
11- MORLEY C.J., DAVIS P.G., DOYLE L.W., BRION L.P. and HASCOET J.M.: COIN Trial Investigators: Nasal CPAP or intubation at birth for very preterm infants. $\mathrm{N}$. Engl. J. Med., 358: 700-708, 2008.

12- JOBE A.H., HILLMAN N., POLGLASE G., KRAMER B.W., KALLAPUR S., et al.: Injury and inflammation from resuscitation of the preterm infant. Neonatology, 94: 190-196, 2008

13-KANMAZ H.G., ERDEVE O., CANPOLAT F.E., MUTLU B. and DILMEN U.: Surfactant administration via thin catheter during spontaneous breathing: Randomized controlled trial. Pediatrics, 13 1: e502, 2013.

14- MAZELA J., MERRITT A., TERRY M.H., GREGORY T.J. and BLOOD A.B.: Comparison of poractant alfa and lyophilized lucinactant in a preterm lamb model of acute respiratory distress. Pediatr. Res., 72: 32-37, 2012.

15- KARLSSON V., HEINEMANN A.B., SJÖRS G., NYKVIST K.H. and AGREN J.: Early skin-to-skin care in extremely preterm infants: Thermal balance and care environment. J. Pediatr., 161: 422-426, 2012.

16- MENESES J., BHANDARI V. and ALVES J.G.: Nasal intermittent positive-pressure ventilation vs nasal continuous positive airway pressure for preterm infants with respiratory distress syndrome: A systematic review and meta-analysis. Arch. Pediatr. Adolesc. Med., 166: 372 376,2012

17- KATTWINKEL J., PERLMAN J.M., AZIZ K., COLBY C., FAIRCHILD K., et al.: Neonatal resuscitation: 2010 American Heart Association guidelines for cardiopulmonary resuscitation and emergency cardiovascular care. Pediatrics, 126: e1400-e1413, 2010.

18- KAUFMAN D.A.: 'Getting to Zero': Preventing invasive Candida infections and eliminating infection-related mortality and morbidity in extremely preterm infants. Early Hum. Dev., 88: S45-S49, 2012.

19- KIERAN E.A., TWOMEY A.R., MOLLOY E.J., MURPHY J.F. and O'DONNELL C.P.: Randomized trial of prongs or mask for nasal continuous positive airway pressure in preterm infants. Pediatrics, 130: e1170-e1176, 2012.

20- KUO H.T., LIN H.C., TSAI C.H., CHOUC I.C. and YEH T.F.: A follow-up study of preterm infants given budesonide using surfactant as a vehicle to prevent chronic lung disease in preterm infants. J. Pediatr., 156: 537-541, 2010. 


\section{دراسلحتدقيقية (أستخدام السيرفاكتانت فى الأطفال الخداج)

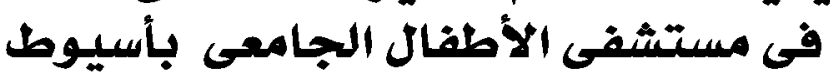

أستخدام المادة الفعالة للسطح فى علاج متلازمة الغشاء الزجاجى أتيح منذ Vr عام مما أحدث ثودة عام .191. أدت المادة الفعالة للسطع مع الكودتيزنف فيما قبل الولادة إلى احسين نجاة الأطفال الخدع التى تعانى من متلازمة الضائقة التنفسية نتيجة متلازمة الغشاء الزجاجى.

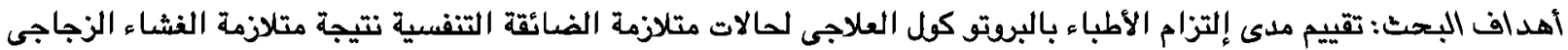

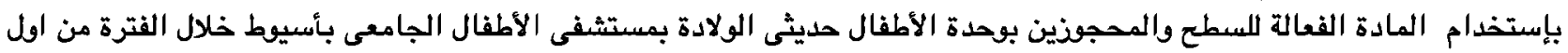

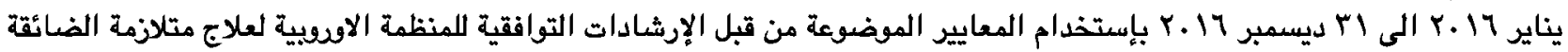

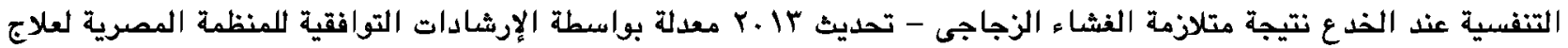

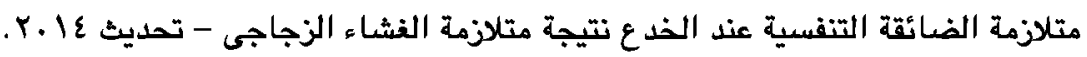
الأطفال الهستهدفين: كل الأطفال الخدع الذين يعانون من متلازمة الضائقة التنفسية نتيجة متلازمة الغشاء الزجاجى المحجوزين

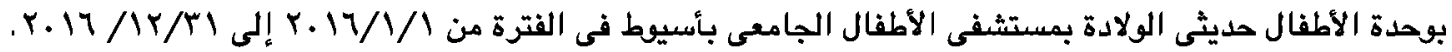
الأطفال المستبعدين :كل الاطفال الخدع الذين يعانون من متلازمة الضائقة التنفسية نتيجة لسبب غير متلازمة الغشاء الزجاجى النتائج: تتضمن الرسالة ـ0 حالة يعانون من متلازمة الضائقة التفسية نتيجة متلازمة الغشاء الزجاجى عدد الذكور با وعدد الإناث

وأظهرت بيانات الدراسة أن الأنظمة العلاجية المستخدمة فى علاج متلازمة الضائقة التنفسية نتيجة متلازمة الغشاء الزجاجى اتبعت جزئياً المعايير المرجعية للدراسة.

$$
\begin{aligned}
& \text { - تم أستيفاء اليانات الخاصة بالعمر لبجينى والنوع والوزن في ... ٪ من الحالات }
\end{aligned}
$$

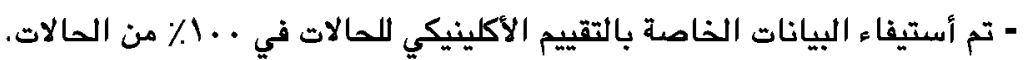

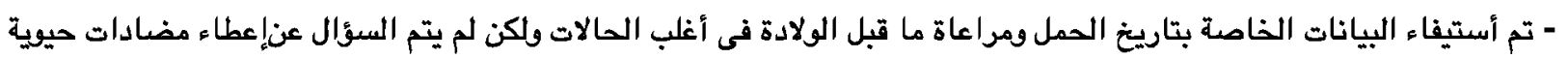

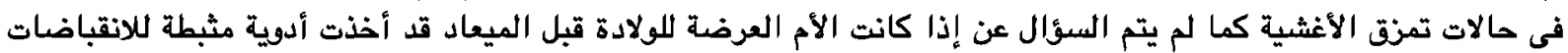

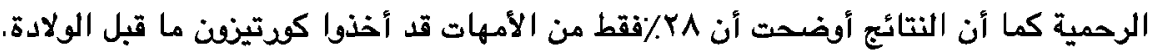

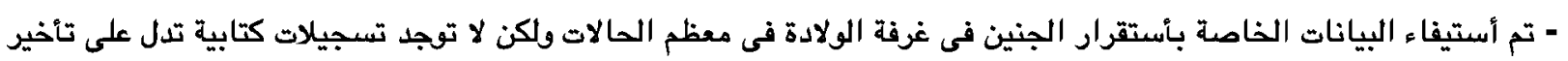

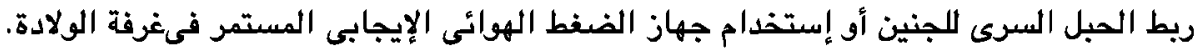

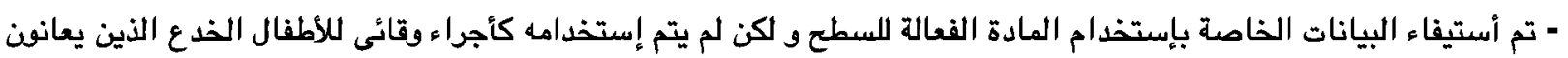
من متلازمة الضائقة التنفسية نتيجة متلازمة الغشاء الزياء الزباجي.

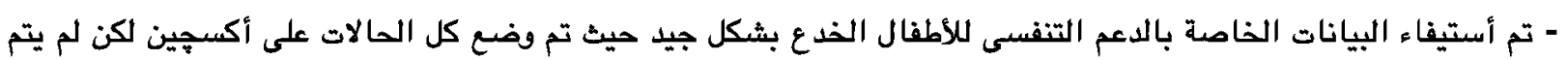

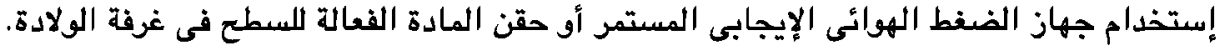

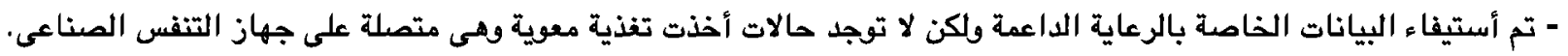

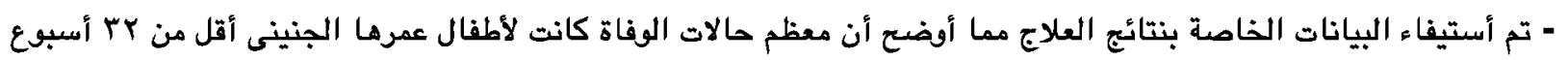

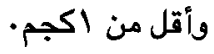

